\title{
ADSORPSI IONTEMBAGA (Cu) DAN ION BESI (Fe) DENGAN MENGGUNAKAN ARANG HAYATI (BIOCHARCOAL) KULIT PISANG RAJA (Musa sapientum)
}

\section{Adsorption of Copper (Cu) and Iron (Fe) Ions using Biocharcoal of Plantain bark (Musa sapientum)}

\author{
* Nirmala, Vanny M. A. Tiwow, dan Suherman \\ Pendidikan Kimia/FKIP - Universitas Tadulako, Palu - Indonesia 94118 \\ Received 10 September 2015, Revised 09 October 2015, Accepted 08 November 2015
}

\begin{abstract}
This study determine the contact time, $p H$, and the optimum concentration of the solution of copper (Cu) and iron ( $\mathrm{Fe}$ ) from skin the plantain (musa sapientum). Advances in the industry today resulted in many human activities that caused increasing impact of the pollution on surrounding of the environment. Environmental pollution by heavy metals being a serious problem along with increasing the use of heavy metals in the industry. The method used in this study was a laboratory experiment using colorimeter. The results showed that the adsorption of copper and iron on the plantain bark influence a time variation of $\mathrm{Cu}$ and $\mathrm{Fe}$ occurred in the 60 minute and 30 minute (99.64\% and 99.54\%); variation of $\mathrm{pH}$ for $\mathrm{Cu}$ and $\mathrm{Fe}$ occurrs in $\mathrm{pH} 4$ and $\mathrm{pH} 3$ (99.62\% and 99.58\%) and variation of concentration for $\mathrm{Cu}$ and Fe occurred at $20 \mathrm{ppm}$ and $1 \mathrm{ppm}$ (80.74\% and 96.81\%), respectively.
\end{abstract}

Keywords: Adsorption, copper $(\mathrm{Cu})$ and iron $(\mathrm{Fe})$, plantain bark (musa sapientum), Biocharcoal.

\section{Pendahuluan}

Kemajuan di bidang industri dimasa sekarang ini mengakibatkan banyaknya aktivitas manusia yang menyebabkan dampak pencemaran lingkungan di sekitarnya meningkat. Pertambahan jumlah industri dan penduduk membawa akibat bertambahnya beban pencemaran yang disebabkan oleh pembuangan limbah industri dan domestik. Pencemaran lingkungan oleh logam berat menjadi masalah yang cukup serius seiring dengan penggunaan logam berat dalam bidang industri yang semakin meningkat. Logam berat banyak digunakan karena sifatnya yang dapat menghantarkan listrik dan panas serta dapat membentuk logam paduan dengan logam lain (Darmayanti dkk., 2012)

Pada umumnya semua logam berat tersebar di seluruh permukaan bumi, tanah, air, maupun udara. Beberapa diantaranya berperan penting dalam kehidupan makhluk hidup dan disebut sebagai hara mikro esensial. Secara biologis

*Correspondence:

Nirmala

Program Studi Pendidikan Kimia, Fakultas Keguruan dan Ilmu Pendidikan, Universitas Tadulako

email: nirmala_paepa@yahoo.co.id

Published by Universitas Tadulako 2015 beberapa logam dibutuhkan oleh makhluk hidup pada konsentrasi tertentu dan dapat berakibat fatal apabila tidak dipenuhi. Oleh karena itu logam-logam tersebut dinamakan logam-logam esensial masuk dalam tubuh dengan jumlah berlebihan, akan berubah fungsi menjadi racun bagi tubuh. Semua logam berat dapat menjadi racun yang akan meracuni tubuh makhluk hidup (Palar, 2008). Walaupun pada konsentrasi rendah, efek ion logam berat dapat berpengaruh langsung hingga terakumulasi melalui rantai makanan yang merupakan ancaman bagi hewan dan manusia (Chen, dkk., 1996).

Berbagai upaya yang telah dilakukan, baik oleh pemerintah maupun masyarakat untuk menanggulangi pencemaran lingkungan antara lain penyuluhan dan penataan lingkungan. Namun, usaha tersebut tidak akan berhasil jika tidak ada dukungan dan kepedulian masyarakat terhadap lingkungan. Selama ini pemanfaatan pisang masih terbatas buahnya saja, namun masih banyak lagi bagian dari tanaman pisang yang sangat berguna. Salah satunya yaitu kulit buah pisang, namun kulit pisang sangat jarang dimanfaatkan oleh masyarakat. Kulit buah pisang umumnya digunakan sebagai makanan ternak dan hanya dibuang begitu saja sebagai 
sampah. Hal ini tidak memberikan nilai ekonomis bagi masyarakat dan negara.

Logam berat yang dibuang ke lingkungan cenderung tidak terdegradasi, tersirkulasi dan biasanya terakumulasi melalui rantai makanan yang merupakan ancaman bagi hewan dan manusia (Chen, dkk., 1996). Dampak dari keberadaan logam berat dalam organisme hidup dapat menghambat aktivitas enzim, termasuk sistem antioksidan (Chen, dkk., 1996). Ion-ion logam berat bersifat toksik meskipun pada konsentrasi yang rendah(dalam ppm) dan umumnya sebagai polutan utama bagi lingkungan (Supriyanto, 2012).

Penelitian tentang pemanfaatan bahanbahan organik yang dijadikan sebagai bahan penyerap telah banyak dilakukan, bahanbahan organik tersebut diubah menjadi arang hayati untuk mengadsorpsi logam berat sehingga dapat mengurangi pencemaran dan penyakit yang diakibatkan logam-logam berat tersebut (Kawasaki dkk., 2006). Arang hayati adalah hasil dari proses pemanasan biomassa menggunakan suhu tinggi (Cahayaningtyas dkk., 2012)

Penelitian sebelumnya tentang pembuatan arang hayati atau biocharcoal telah dilakukan oleh Radyawati (2011) dengan menggunakan limbah organik yaitu kulit pisang dimana charcoal atau arang hayati yang dihasilkan dapat digunakan untuk mengadsorpi logam $\mathrm{Pb}$ dan $\mathrm{Zn}$ sehingga dapat mengurangi pencemaran akibat logam-logam berat tersebut. Sedangkan Darmayanti dkk (2012) juga telah melakukan penelitian tentang adsorpsi timbal $(\mathrm{Pb})$ dan zink $(\mathrm{Zn})$ dari larutannya dengan menggunakan arang hayati (biocharcoal) dari kulit pisang kepok berdasarkan variasi $\mathrm{pH}$, dimana pada penelitian ini diperoleh bahwa adsorpsi optimum logam timbal $(\mathrm{Pb})$ yaitu pada pH 4 sedangkan untuk logam zink ( $\mathrm{Zn})$ pada pH 6. Teknik adsorpsi terhadap logam berat telah banyak dilakukan dengan menggunakan berbagai macam adsorben, yakni penghilangan ion arsen dari larutan menggunakan arang hayati Ansari \& Sadegh (2007). Adsorpsi ion logam $\mathrm{Cu}$ (II) menggunakan lignin dari limbah serbuk kayu gergaji oleh Lelifajri (2010), Zamrudy (2008) sebagai bahan baku pembuatan biocharcoal untuk mengadsorpsi logam berat.

Tulisan ini mengurai hasil penelitian mengenai adsorpsi ion tembaga $(\mathrm{Cu})$ dan besi $(\mathrm{Fe})$ menggunakan arang hayati (Biocharcoal) kulit pisang raja (Musa sapientum).

\section{Metode}

\section{Alat dan Bahan}

Alat yang digunakan pada penelitian ini adalah neraca analitik, gelas ukur $100 \mathrm{~mL}$, corong, erlemeyer $100 \mathrm{~mL}$, gelas kimia $50 \mathrm{~mL}$, ayakan 200 mesh, pH meter, shaker, botol semprot, labu ukur $50 \mathrm{~mL}, 100 \mathrm{~mL}$, dan 1000 $\mathrm{mL}$, pipet gondok $10 \mathrm{ml}$ dan $25 \mathrm{ml}$, pipet tetes, colorimeter. Sedangkan bahan yang digunakan yaitu biocharcoal kulit pisang, larutan sampel $\mathrm{CuSO}_{4}$ Ajak Chemicals, larutan sampel $\mathrm{Fe}\left(\mathrm{NO}_{3}\right)_{2}$ Ajak Chemicals, kertas aluminium foil, aquades, $\mathrm{HNO}_{3}$ Smart lab, $\mathrm{NH}_{4} \mathrm{OH}$ Merck, lamotte copper I, lamotte iron powder I dan lamotte powder II, tissue dan kertas saring Whatman 41.

\section{Prosedur kerja \\ Pembuatan arang hayati (biocharcoal) dari kulit pisang raja}

Kulit pisang raja dibersihkan dari sisa-sisa kotoran, lalu sampel tersebut dikeringkan pada sinar matahari selama \pm 5 hari. Selanjutnya, sampel kulit pisang raja yang telah kering dimasukkan ke dalam kaleng (alat pembuatan arang), sampel tersebut dibakar dalam keadaan tertutup sampai menjadi arang dan didinginkan. Biocharcoal yang terbentuk dihaluskan dengan menggunakan lumpang dan alu, dan diayak menggunakan ayakan 200 mesh.

\section{Pengaruh waktu kontak Biocharcoal}

Biocharcoal dengan berat masingmasing $60 \mathrm{mg}$ dibuat 2 deret. Deret pertama ditambahkan dengan $25 \mathrm{~mL}$ larutan tembaga 100 ppm, pada $\mathrm{pH} 4$ dan deret kedua ditambahkan dengan $25 \mathrm{~mL}$ larutan besi 100 ppm, pada pH 2. Selanjutnya, tabung erlenmeyer ditutup dengan kertas aluminium foil dan dikocok dengan shaker selama 30, 45, 60 dan 90 menit, kemudian mendiamkannya selama 24 jam. Setelah itu, memisahkan filtrat dan residu dengan penyaringan menggunakan kertas saring Whatman 41. Selanjutnya, mengukur adsorbansi larutan sampel dengan menggunakan instrumen alat Colorimeter.

\section{Pengaruh variasi $p H$ larutan tembaga dan besi \\ Sebanyak $25 \mathrm{~mL}$ larutan tembaga dan} besi masing-masing berkonsentrasi $60 \mathrm{mg} / \mathrm{L}$ dibuat dengan mengencerkan larutan induk, kemudian $\mathrm{pH}$ diatur sebesar 2, 3, 4 atau 5 atau sampai keruh untuk larutan tembaga dan $\mathrm{pH}$ 2, 3, 4, 5 atau sampai keruh untuk larutan besi dengan menambahkan $\mathrm{HNO}_{3}$ atau $\mathrm{NH}_{4} \mathrm{OH}$. Kemudian masing-masing larutan yaitu 
tembaga dan besi dicampurkan dengan $60 \mathrm{mg}$ biocharcoal dalam tabung erlenmeyer $100 \mathrm{~mL}$, selanjutnya ditutup dengan kertas aluminium foil, diikat dengan karet dan dishaker selama 60 menit untuk larutan tembaga dan 45 menit untuk laruten besi, kemudian mendiamkannya selama 24 jam. Setelah itu, memisahkan filtrat dan residu dengan penyaringan menggunakan kertas saring Whatman 41. Selanjutnya, mengukur adsorbansi larutan sampel dengan menggunakan instrumen alat Colorimeter.

\section{Pengaruh variasi konsentrasi ion tembaga dan ion besi}

Membuat $25 \mathrm{~mL}$ larutan besi dan tembaga dengan masing-masing konsentrasi berturutturut 10, 20, 30 dan $40 \mathrm{ppm}$ untuk tembaga dan untuk besi 1, 2, 3 dan 4 ppm, kemudian mengatur $\mathrm{pH}$ larutan tembaga menjadi 4 dan $\mathrm{pH}$ besi menjadi 3. Selanjutnya, mengukur konsentrasi awal dari larutan ini dengan menggunakan instrumen alat Collorimeter. Selanjutnya, masing-masing larutan besi dan tembaga tersebut dicampur biocharcoal dengan berat $60 \mathrm{mg}$ dimasukkan dalam tabung erlenmeyer $100 \mathrm{~mL}$. Kemudian, erlenmeyer ditutup dengan kertas aluminium foil dan selanjutnya dikocok dengan shaker selama 60 menit untuk larutan tembaga dan 45 menit untuk larutan besi, kemudian mendiamkannya selama 24 jam. Setelah itu, memisahkan filtrat dan residu dengan penyaringan menggunakan kertas saring Whatman 41 dan mengukur adsorbansi larutan dengan menggunakan instrumen alat Colorimeter.

\section{Analisa Data}

Analisa presentasi adsorpsi (efisiensi adsorpsi) menggunakan persamaan sebagai berikut (Atkins, 1999):

$\mathrm{Cb}=\mathrm{Ci}-\mathrm{Ceq}$ dan \% logam terserap $=\mathrm{Cb} /$ $\mathrm{Ci} \times 100 \%$ diimana, $\mathrm{Cb}$ adalah konsentrasi $\mathrm{Zn}$ dan $\mathrm{Cu}$ yang terserap $(\mathrm{mg} / \mathrm{L}) ; \mathrm{Ci}$ adalah konsentrasi awal larutan (mg/L); dan Ceq adalah konsentrasi akhir larutan (mg/L).

\section{Hasil dan Pembahasan}

Proses pembakaran kulit pisang raja berlangsung selama 30 menit pada kondisi oksigen rendah sampai menjadi arang. Setelah menjadi arang, sampel tersebut dibiarkan dingin dan kemudian sampel kulit pisang raja tersebut akan dihaluskan dengan cara ditumbuk menggunakan lumpang dan alu dan diayak menggunakan ayakan 200 mesh untuk menghasilkan ukuran partikel adsorben yang lebih halus atau yang memiliki luas permukaan yang optimal. Langkah tersebut sesuai dengan pernyataan (Oscik \& Cooper (1982) yang menyatakan bahwa efisiensi adsorpsi merupakan fungsi luas permukaan adsorben. Semakin besar luas permukaan adsorben semakin besar pula kapasitas suatu adsorben dalam mengadsorpsi suatu adsorbat. Proses pengayakan ini merupakan tahap kerja terakhir pada proses pembuatan biocharcoal.

Penentuan konsentrasi ion tembaga dan ion besi dalam keadaan kesetimbangan diukur menggunakan colorimeter, masing-masing panjang gelombangnya $430 \mathrm{~nm}$ dan 520 nm. Jumlah logam kadmium terserap oleh biocharcoal kulit pisang raja adalah selisih konsentrasi ion tembaga dan ion besi mulamula dengan konsentrasi ion tembaga dan ion besi pada saat kesetimbangan.

Hasil serapan logam tembaga dan logam besi yang maksimum dari variasi $\mathrm{pH}$, waktu kontak dan konsentrasi maka memerlukan suatu kondisi optimum, yang merupakan variabel penelitian ini. Kondisi optimum didefinisikan sebagai kondisi perlakuan yang dapat memberikan hasil arang terbaik didasarkan pada besarnya rendemen yang dihasilkan dan daya adsorpsinya (Hartoyo dkk., 1990).

Variasi waktu kontak terhadap adsorpsi ion tembaga dan ion besi

\section{Untuk larutan tembaga $(\mathrm{Cu})$}

Berdasarkan data yang disajikan Gambar 1 menunjukkan pada waktu 60 menit sampai 60 menit terjadi peningkatan dari $99,42 \%$ menjadi 99,64\%, namun kembali menurun pada waktu 90 menit dengan persentase $99,52 \%$. Sehingga yang menjadi waktu optimum pada waktu 60 menit.

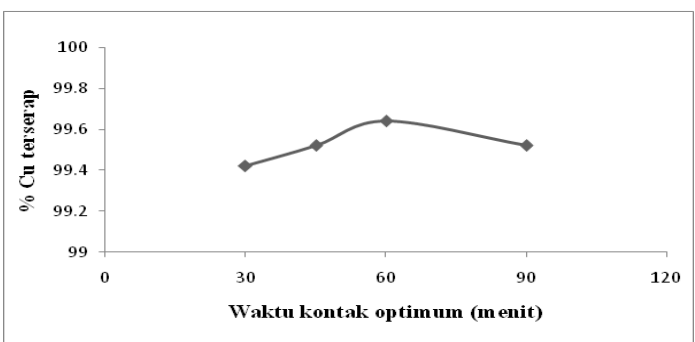

Gambar 1 Kurva hubungan antara waktu kontak optimum (menit) terhadap \%Cu terserap

Peningkatkan adsorpsi pada waktu 60 menit tersebut dikarenakan keaktifan penyerapan pada biocharcoal kulit pisang raja pada larutannya, dan proses penyerapan ini berlangsung sangat cepat dan efektif. Proses adsorpsi juga dipengaruhi oleh besar kecilnya ukuran adsorben yang digunakan 
yang menyebabkan luas permukaan sentuhnya relatif besar sehingga kemungkinan terjadinya interaksi yang sangat efektif antara sisi aktif pada adsoben dengan ion logam (Khopkar, 2003). Terjadi penurunan kembali pada waktu 90, dimana proses penyerapan ion logam tembaga sebesar $99,52 \%$. Variasi waktu kontak antara ion logam dengan adsoben yaitu biocharcoal kulit pisang raja terbukti sangat mempengaruhi daya serap ion logam tembaga. Semakin lama waktu kontak suatu sampel mengakibatkan penyerapan yang terjadi akan meningkat sampai mencapai waktu optimum dan setelah itu akan turun kembali pada waktu yang divariasikan. Maka dalam penelitian ini, waktu kontak optimum diperoleh pada menit ke 60 dimana penyerapan akan logam tembaga sebesar $99,64 \%$.

\section{Untuk larutan besi $(\mathrm{Fe})$}

Penentuan pada adsorpsi ion timbal pada variasi waktu kontak pada biocharcoal kulit pisang raja menggunakan waktu 30 menit, 45 menit, 60 menit dan 90 menit. Variasi waktu tersebut bertujuan untuk mengetahui berapa waktu optimum dari larutan tembaga terhadap adsorben biocharcoal kulit pisang raja.

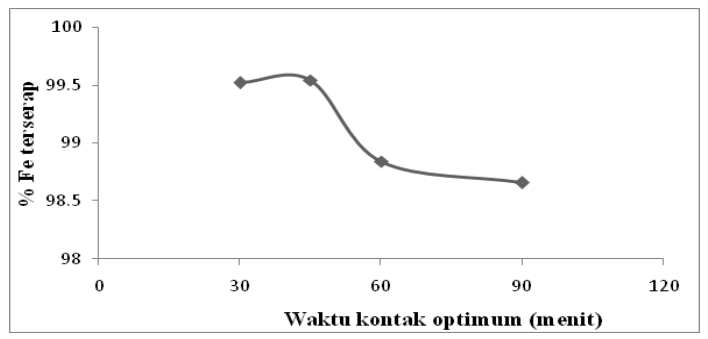

Gambar 2 Kurva hubungan antara waktu kontak optimum (menit) terhadap \%Fe terserap

Berdasarkan data yang disajikan Gambar 2 di atas waktu adsorben meningkat dari 30 menit sampai 45 menit dengan persentase masing-masing sebesar $99,52 \%$ meningkat menjadi $99,54 \%$ dan menurun pada waktu 60 menit sampai 90 menit $98,84 \%$ menjadi $98,66 \%$. Sehingga ada waktu 45 menit ini yang menjadi waktu optimum dengan persentase sebesar $99,54 \%$. Hal ini terjadi karena ionion tembaga yang terdapat di dalam larutan telah teradsorpsi sepenuhnya oleh arang hayati, dengan kata lain ion-ion tembaga pada larutan telah habis teradsorpsi oleh arang hayati. Selain itu, hal tersebut juga dapat terjadi karena permukaan arang hayati sudah dalam keadaan jenuh dengan ion-ion logam tembaga sehingga peningkatan berat arang hayati relatif tidak lagi mempengaruhi peningkatkan penyerapan ion logam oleh arang hayati (Radyawati, 2011).

Berdasarkan uraian di atas maka dapat diketahui bahwa adsorpsi optimum ion besi terjadi pada 45 menit arang hayati dengan persentase serapan yaitu $99,54 \%$.

\section{Variasi $\mathrm{pH}$ larutan terhadap Adsorpsi Ion Tembaga dan Ion Besi \\ Untuk larutan tembaga (Cu)}

Derajat keasaman $(\mathrm{pH})$ merupakan faktor yang sangat mempengaruhi proses adsorpsi ion logam dalam larutan, karena keberadaan ion $\mathrm{H}^{+}$dalam larutan akan berkompetensi dengan kation untuk berikatan dengan situs aktif. Selain itu, $\mathrm{pH}$ juga akan mempengaruhi spesies ion yang ada dalam larutan sehingga akan mempengaruhi terjadinya interaksi ion dengan situs aktif adsorben (Lestari, 2010).

Penentuan $\mathrm{pH}$ optimum pada adsorpsi ion tembaga menggunakan arang hayati kulit pisang raja dilakukan pada variasi $\mathrm{pH} 2,3,4$ dan 5. Penentuan $\mathrm{pH}$ optimum ini bertujuan untuk mengetahui $\mathrm{pH}$ optimum dari adsorpsi larutan ion tembaga oleh arang hayati.

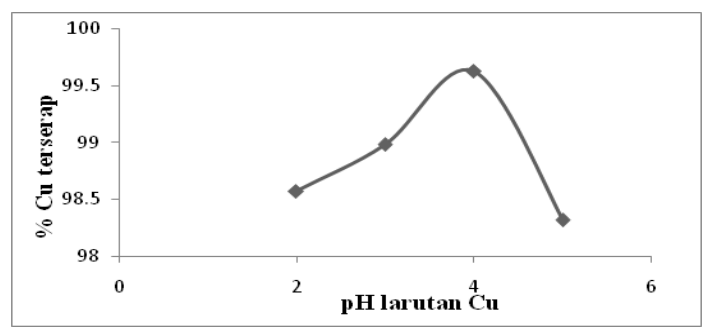

Gambar 3 Kurva hubungan antara $\mathrm{pH}$ larutan terhadap \%Cu terserap

Berdasarkan Gambar 3 di atas terlihat bahwa serapan tembaga dipengaruhi oleh larutan, dimana $\mathrm{pH} 2$ sampai $\mathrm{pH} 3$ penyerapan tembaga tidak terlalu besar dengan persentase masing-masing sebesar $98,57 \%$ menjadi $98,98 \%$, sedangkan pada $\mathrm{pH} 5$ penyerapan tembaga menurun dengan serapan sebesar $98,32 \%$. Sehingga terjadi adsorpsi ion tembaga oleh arang hayati kulit pisang raja yang konstan pada $\mathrm{pH} 4$ dimana persentase serapannya sebesar $99,62 \%$.

Rendahnya penyerapan yang terjadi pada pH 2 sampai 3 ini disebabkan karena adanya beberapa kemungkinan yaitu pertama, karena pada $\mathrm{pH}$ rendah terjadi persaingan antara $\mathrm{H}^{+}$ dengan $\mathrm{Cu}^{2+}$ untuk berinteraksi dengan gugus fungsional yang ada pada permukaan arang hayati kulit pisang raja; kedua, pada $\mathrm{pH}$ rendah gugus fungsional yang ada pada permukaan 
arang hayati kulit pisang raja dikelilingi oleh ion $\mathrm{H}^{+}$sehingga mencegah terjadinya interaksi antara ion tembaga dengan gugus fungsi pada permukaan arang hayati kulit pisang raja (Tumin dkk., 2008) dan ketiga, permukaan arang hayati kulit pisang raja bermuatan positif sehingga terjadi penolakan secara elektrostatik terhadap ion $\mathrm{Cu}^{2+}$ (Sharma dkk., 2009). Sedangkan pada $\mathrm{pH} 4$ adsorpsi yang terjadi sangat besar yaitu 99,62\% hal ini disebabkan karena jumlah ion $\mathrm{H}^{+}$mulai berkurang sehingga dengan $\mathrm{H}^{+}$berkurang dan permukaan arang hayati kulit pisang raja cenderung terionisasi dengan melepas ion $\mathrm{H}^{+}$dan permukaan arang hayati kulit pisang raja menjadi negatif (Vasu, 2008) sehingga terjadi interaksi elektrostatik antara permukaan biocharcoal kulit pisang raja dengan ion $\mathrm{Cu}^{2+}$. Namun, pada $\mathrm{pH} 5$ penyerapannya menurun. Penurunan tersebut terjadi karena $\mathrm{pH}$ tinggi ion tembaga mengalami tereduksi menjadi ion bermuatan +1 (Wirawan \& Lestari, 2008). Terhidrolisisnya tembaga maka muatan positifnya berkurang menjadi +1 sehingga interaksinya dengan permukaan biocharcoal kulit pisang raja berkurang.

Berdasarkan uraian di atas dapat diketahui adsorpsi optimum ion tembaga terjadi pada $\mathrm{pH}$ 4 dengan persentase serapan yaitu $99,62 \%$.

\section{Untuk larutan besi $(\mathrm{Fe})$}

Penentuan $\mathrm{pH}$ optimum pada adsorpsi besi $(\mathrm{Fe})$ menggunakan adsorben arang hayati kulit pisang raja dilakukan pada $\mathrm{pH} 2,3,4$ dan 5 . Penentuan $\mathrm{pH}$ optimum ini bertujuan untuk mengetahui $\mathrm{pH}$ optimum dari adsorpsi larutan besi $(\mathrm{Fe})$ oleh adsorben arang hayati kulit pisang raja.

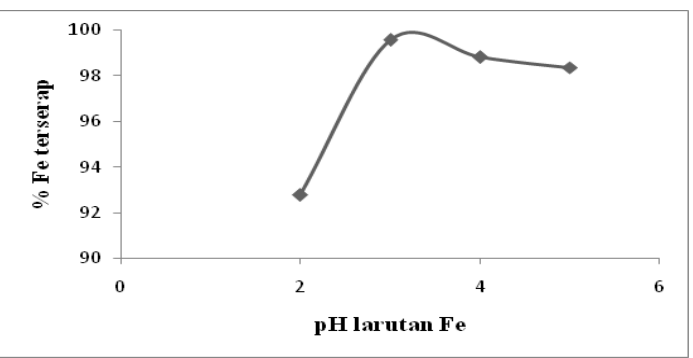

Gambar 4 Kurva hubungan antara $\mathrm{pH}$ larutan terhadap $\%$ Fe terserap

Berdasarkan Gambar 4 terlihat bahwa serapan besi dipengaruhi oleh $\mathrm{pH}$ larutan, dimana pada $\mathrm{pH} 2$ penyerapan besi tidak terlalu besar dengan persentase serapannya $92,77 \%$, sedangkan pada $\mathrm{pH} 4$ dan $\mathrm{pH} 5$ serapan besi menurun dengan persentase serapnya sebesar
$98,8 \%$ menjadi $98,37 \%$, hingga terjadi serapan arang hayati aktif kulit pisang raja serapan optimum yang konstan terjadi pada $\mathrm{pH} 3$.

Rendahnya penyerapan pada $\mathrm{pH} 2$, karena mengalami proses desorpsi, dimana ikatan lemah yang terjadi antara adsorben dengan ion logam akan lepas kembali ke dalam larutannya karena semakin lama waktu kontak (Lestari, 2010). Terjadinya peningkatan adsorpsi ion tembaga pada $\mathrm{pH} 3$, karena kerapatan sel arang hayati dalam larutan sehingga menghasilkan interaksi yang cukup efektif antara pusat aktif dinding sel arang hayati dengan ion besi, semakin banyak zat penyerap maka semakin banyak pusat aktif arang hayati yang bereaksi. Oleh sebab itu, pada saat jumlah arang hayati diperbesar, perbandingan tersebut tidak lagi dipenuhi, sehingga berpengaruh terhadap aktifitas penyerapan ion besi oleh arang hayati (Radyawati, 2011). Rendahnya penyerapan $\mathrm{Fe}^{2+}$ oleh arang hayati aktif pada $\mathrm{pH}$ yang lebih rendah akibat protonasi gugus basa (fungsional) bahan penyerap, sehingga situs aktif memiliki muatan cenderung positif, akibatnya interaksi antara kation dengan situs aktif berkurang atau bahkan hilang. Sebaliknya kenaikan $\mathrm{pH}$ mengakibatkan situs aktif yang berarti kapasitas serapan meningkat.

Rendahnya adsorpsi pada $\mathrm{pH} 4$ sampai $\mathrm{pH}$ 5 ini disebabkan karena masih banyak ion $\mathrm{H}^{+}$ yang mengelilingi dinding permukaan arang hayati kulit pisang raja sehingga mencegah terjadinya interaksi antara ion besi dengan gugus fungsi fungsi pada permukaan arang hayati kulit pisang raja (Wirawan \& Lestari, 2008).

Berdasarkan uraian di atas dapat diketahui adsorpsi optimum ion besi terjadi pada $\mathrm{pH} 3$ dengan persentase serapan yaitu $99,58 \%$.

\section{Variasi Konsentrasi larutan terhadap Adsorpsi Ion Tembaga dan Ion Besi oleh Biocharcoal Untuk larutan tembaga ( $\mathrm{Cu}$ )}

Penentuan konsentrasi setelah pengukuran pada adsorpsi logam tembaga menggunakan adsorben arang hayati aktif kulit pisang raja dilakukan pada pada variasi konsentrasi untuk logam tembaga 10 ppm, 20 ppm, $30 \mathrm{ppm}$ dan $40 \mathrm{ppm}$. Penentuan konsentrasi ini bertujuan untuk mengetahui konsentrasi optimum dari adsorpsi larutan tembaga oleh adsorben arang hayati aktif kulit pisang raja.

Berdasarkan Gambar 5 terlihat bahwa serapan ion tembaga mengalami peningkatan dari konsentrasi 10 ppm sampai 20 ppm 


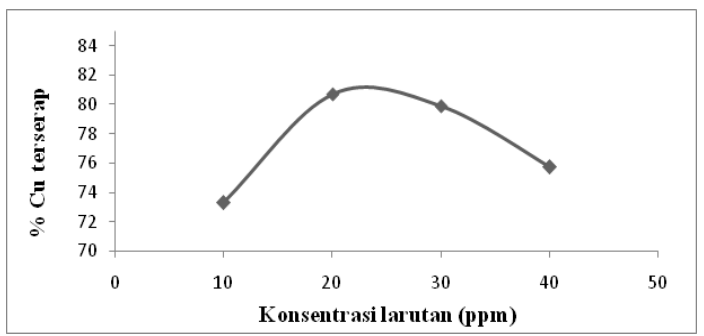

Gambar 5 Kurva hubungan antara konsentrasi larutan terhadap \%Cu terserap

Adsorpsi ion tembaga mengalami peningkatan pada konsentrasi $10 \mathrm{ppm}$ sampai 20 ppm dengan serapan yaitu sebesar 73,33\% meningkat menjadi 80,74 \% dan pada konsentrasi 30 ppm sampai 40 ppm serapan tembaga menurun dengan persentase serapan masing-masing sebesar $79,92 \%$ menjadi $75,72 \%$. Sehingga konsentrasi optimum terjadi pada konsentrasi $20 \mathrm{ppm}$. Hal ini dikarenakan bila konsentrasi suatu larutan dinaikkan maka akan menyebabkan terjadinya peningkatan jumlah ion yang terikat pada adsorben sehingga nilai kapasitas penjerapannya meningkat (Apriliani, 2010). Hal ini pun dapat terjadi bila jumlah partikel adsorban biocharcoal kulit pisang raja lebih banyak dibandingkan dengan partikel ion logam tembaga sehingga proses penjerapan akan bertambah. Berdasarkan uraian di atas maka dapat diketahui bahwa adsorpsi optimum ion tembaga terjadi pada konsentrasi 20 ppm dengan serapan yaitu $80,74 \%$.

\section{Untuk larutan besi $(\mathrm{Fe})$}

Hasil serapan logam $\mathrm{Fe}$ yang maksimum memerlukan suatu kondisi optimum. Variasi konsentrasi yang digunakan yaitu $1 \mathrm{ppm}, 2$ ppm, 3 ppm, 4 ppm dan 5 ppm. Adsorpsi ion besi mengalami penurunan pada konsentrasi 1 ppm sampai 4 ppm dengan persentase serapan masing-masing yaitu 96,81 \%, 79,415, $80,39 \%$ dan $81,67 \%$.

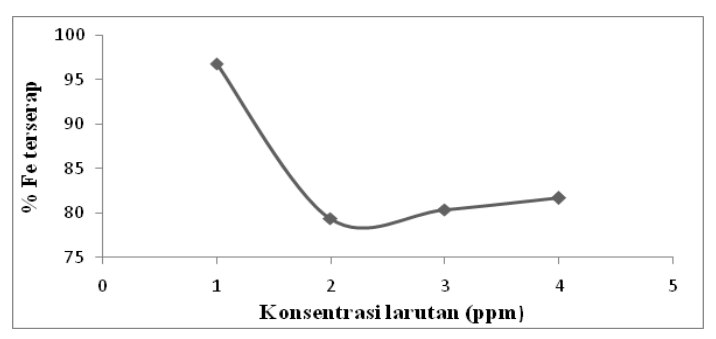

Gambar 6 Kurva Hubungan antara Konsentrasi larutan terhadap \%Fe Terserap

Terjadinya penyerapan pada ion besi yang diperoleh pada 1 ppm dengan persentase serapan adalah sebesar 96,81\%. Hal ini terjadi karena bila konsentrasi suatu larutan dinaikkan maka akan menyebabkan terjadinya peningkatan jumlah ion yang terikat pada adsorben sehingga nilai kapasitas penjerapannya meningkat (Apriliani, 2010). Hal ini pun dapat terjadi bila jumlah partikel adsorban arang hayati kulit pisang raja lebih banyak dibandingkan dengan partikel ion logam besi sehingga proses penjerapan akan bertambah. Akan tetapi terjadi penurunan pada kosentrasi larutan 2 ppm sampai 4 ppm. Serapan ion besi tersebut menurun mencapi $81,67 \% \%$. Hal ini disebabkan meningkatnya konsentrasi ion logam, proses penyerapan yang terjadi pada sampel akan berkurang dan jumlah ion logam dalam larutan tidak akan sebanding dengan jumlah partikel arang hayati kulit pisang raja sehingga permukaan biocharcoal kulit pisang raja akan mencapai titik jenuh dan kemungkinan akan terjadi proses pelepasan kembali antar adsorben dengan adsorbat. Hal ini terjadi karena dipengaruhi oleh konsentrasi larutan, semakin besar konsentrasi larutan maka adsorpsi ion besi juga akan semakin menurun sampai batas konsentrasi tertentu. Dalam hal ini arang hayati belum jenuh oleh ion besi maka dengan memperbesar konsentrasi ion besi jumlah zat yang terserap akan meningkat secara linear. Selanjutnya jika pusat aktif telah jenuh dengan ion logam maka peningkatan konsentrasi ion logam relatif tidak meningkatkan penyerapan ion logam oleh arang hayati (Radyawati, 2011).

Logam berat mempunyai sifat yang mudah mengikat bahan organik dan mengendap di dasar perairan dan bersatu dengan sedimen sehingga kadar logam berat dalam sedimen lebih tinggi dibandingkan dalam air. logam berat memiliki sifat yang mudah mengikat dan mengendap di dasar perairan dan bersatu dengan sedimen (Amriani dkk., 2011)

Berdasarkan uraian di atas maka dapat diketahui bahwa adsorpsi optimum ion besi terjadi pada konsentrasi 1 ppm dengan serapan yaitu $96,81 \%$.

\section{Kesimpulan}

Waktu optimum yang diperlukan biocharcoal kulit pisang raja untuk menyerap ion tembaga adalah 60 menit dengan serapannya sebesar $99,64 \%$ sedangkan untuk ion besi adalah 45 menit dengan serapannya sebesar 99,54\%. Adsorpsi optimum ion tembaga terjadi pada $\mathrm{pH} 4$ dengan serapan $99,62 \%$ dan ion besi terjadi pada $\mathrm{pH} 3$ dengan serapan 99,58\%. Adsorpsi optimum ion tembaga terjadi pada konsentrasi $20 \mathrm{ppm}$ 
dengan persentase serapannya $80,74 \%$, dan ion besi terjadi pada konsentrasi $1 \mathrm{ppm}$ dengan persentase serapan sebesar 96,81\%.

\section{Ucapan Terima Kasih}

Penulis mengucapkan terima kasih kepada kepala laboran laboratorium Agroteknologi Fakultas Pertanian dan semua pihak yang telah membantu dalam pelaksanaan penelitian ini.

\section{Referensi}

Amriani, Hendrarto, B., \& Hadiyart, A. (2011). Bioakumulasi logam berat timbal $(\mathrm{Pb})$ dan seng ( $\mathrm{Zn}$ ) pada kerang darah (anadara granosa L.) dan kerang bakau (polymesoda bengalensis L.) di Perairan Teluk Kendari. Jurnal Ilmu Lingkungan, 9(2), 45-50.

Ansari, R., \& Sadegh, M. (2007). Application of activated carbon for removal of arsenic ions from aqueous solutions. E-Journal of Chemistry, 4(1), 103-108.

Apriliani, A. (2010). Manfaat arang dari ampas tebu untuk menyerap ion logam $\mathrm{Cd}, \mathrm{Cr}, \mathrm{Cu}$ dan $\mathrm{Pb}$ dalam air limbah. Skripsi. Jakarta: UIN Syarif Hidayatullah.

Atkins, P. W. (1999). Kimia fisik 2. Jakarta: Erlangga.

Cahayaningtyas, W. P., \& Sumantri, I. (2012). Pengaruh penambahan biochar limbah pertanian dan pestisida pada inkubasi tanah inceptisol untuk menekan emisi gas metana sebagai gas rumah kaca. Jurnal Teknologi Kimia dan Industri, 1(1), 521-527.

Chen, J. P., Chen, W. R., \& Hsu, R. C. (1996). Biosorpsion of copper from aqueous solution by plant root tissues. Journal of Fermentation and Bioengineering, 81(5), 458-463.

Darmayanti, Rahman, N., \& Supriadi. (2012). Adsorpsi timbal (Pb) dan zink $(\mathrm{Zn})$ dari larutannya menggunakan arang hayati (biocharcoal) kulit pisang kepok berdasarkan variasi $\mathrm{pH}$. Jurnal Akademika Kimia, 1(4), 159-165.

Hartoyo, Hudaya, \& Fadli. (1990). Pembuatan arang aktif dari tempurung kelapa dan kayu bakau dengan aktivasi uap. Jurnal Penelitian Hasil Hutan, 18(1), 8-16.

John, R., Ahmad, P., Gadgil, K., \& Sharma,
S. (2009). Heavy metal toxicity: Effect on plant growth, biochemical parameters and metal accumulation by brassica juncea 1 . International Journal of Plant Production, 3(3), 65-76.

Kawasaki, N., Bun-ei, R., Ogata, F., Nakamura, T., Tanei, S., \& Tanada, S. (2006). Water treatment technology using carbonaceus material produced from vegetable biomass. Journal of Water and Environment Technology, $4(1), 78-82$.

Khopkar, S. M.(2003). Konsep dasar kimia analitik. Jakarta: UI-Press.

Lelifajri. (2010). Adsorpsi ion logam Cu (II) menggunakan lignin dari limbah serbuk kayu gergaji. Jurnal Rekayasa Kimia dan Lingkungan, 7(3), 126-129.

Lestari. (2010). Pengaruh berat dan waktu kontak untuk adsorpsi timbal(II) oleh adsorben dari kulit batang jambu biji (psidium guajaval). Jurnal Kimia Mulawarman, 8(1), 7-8.

Oscik, J., \& Cooper, L. (1982). Adsorption. New York: Ellis Horwood.

Palar, H. (2008). Pencemaran dan toksikologi logam berat. Jakarta: Rineka Cipta.

Radyawati. (2011). Pembuatan biocharcoal dari kulit pisang kepok untuk penyerapan logam timbal $(P b)$ dan logam seng $(Z n)$. Skripsi. Palu: Universitas Tadulako.

Sharma, Y. C., Uma, \& Upadhyay, S. N. (2009). Removal of a cationic dye from wastewater by adsorption on activated carbon developed from coconut coir. Energy and Fuels. (23), 2983-2988.

Supriyanto, R. (2012). Studi analisis spesiasi ion logam $\mathrm{Cr}(\mathrm{III})$ dan $\mathrm{Cr}(\mathrm{VI})$ dengan asam tanat dari ekstrak gambir menggunakan spektrometri UV-Vis. Jurnal Sains MIPA, 17(1), 35-42.

Tumin, N. D., Chuah, A. L., Zawani, Z., \& Rashid, S. A. (2008). Adsorption of copper from aqueous solution by elais guineensis kernel activated carbon. Journal of Engineering Science and Technology, 3(2), 180-189. 
Vasu, A. E. (2008). Surface modification of activated carbon for enhancement of nickel(II) adsorption. E-Journal of Chemistry, 5(4), 814-819.

Wirawan, T., dan Lestari, S. (2008). Pemanfaatan arang hayati aktif tempurung jarak pagar (jatropha curcas) sebagai adsorben timbal $(\mathrm{Pb})$ dan tembaga $(\mathrm{Cu})$. Jurnal Ilmiah Mahakam (7), 59-67.

Zamrudy, W. (2008). Pembuatan karbon aktif dari ampas biji jarak pagar (jatropha curcas linn). Jurnal Teknologi Separasi, 1(2), 151162. 